\title{
Specific Effects of Language Transfer Promoting Teaching and Insights into the Implementation in EFL-Teaching
}

\author{
Kerstin Göbel \\ University of Duisburg-Essen, Faculty of Education \\ Svenja Vieluf \\ German Institute for International Educational Research - DIPF
}

\begin{abstract}
The following contribution analyzes language transfer promoting instruction in the context of English as a foreign language (EFL) instruction in $9^{\text {th }}$ grade secondary classes in Germany. By combining data from questionnaires, tests, and video-data, the article sheds light on learning outcomes in the context of language transfer promoting instruction and presents teaching practice of interlanguage reflection in ESL-teaching. Results indicate a positive correlation of language transfer promoting teaching with EFL listening comprehension at the beginning of grade 9. A correlation between language transfer promoting teaching did not show up with text reconstruction. The analysis of selected videos revealed sequences that hint at an attempt to promoting language transfer actually take place in classes of teachers reporting high importance for language transfer promoting teaching. However, these sequences do not display an elaborated language transfer promoting teaching. Language transfer promotion is implemented in a rather implicit way, while referring to German language only. Results indicate the need for elaborated strategies of implementation of language transfer promoting teaching.
\end{abstract}

Keywords: English as a foreign language teaching, implementation, language transfer promoting teaching

During the last few decades, Europe has been facing continuous migration with growing ethnic and linguistic diversity as a consequence, especially in urban areas (Vertovec, 2007). Consequently, an increase in the number of students with diverse linguistic experiences is noticeable in German schools, accompanied by a growing concern for their educational integration (Hesse, Göbel, \& Hartig, 2008; Stanat, Rauch, \& Segeritz, 2010). Although linguistic diversity can be a challenge for the integration of immigrant students in schools, multilingualism provides a linguistic resource for the psychological and linguistic development of students and for teaching in class. Linguistic proficiency is considered to be a key qualification in a world undergoing migration and globalization (European Commission, 2005). Empirical research points to considerable cognitive advantages of multilinguals in that the knowledge of two or more languages facilitates their learning of additional foreign languages in comparison with monolinguals (Bialystok, 2005; Jessner, 2008). Research has been able to show that multilingual learners possess a higher level of language awareness and more language learning strategies compared to their 
monolingual peers (Cenoz, 2003; Naimann et al., 1996). Language learners seem to apply their language skills from one language to another and, as a result, the more languages learners have available, the more learning techniques and strategies learners develop, helping them to acquire new languages (Hufeisen \& Marx, 2006). However, the lexical register of multilingual speakers is still supposed to be smaller than that of monolinguals (Mägiste, 1984). In addition to the advantages in language learning, bilingualism shows positive effects when general cognitive processes are considered: Regardless of age and social status, bilinguals show a higher competence in selective attention than monolinguals and, bilingualism decelerates dementia (Bialystok \& Poarch, 2015). Therefore, researchers strongly support the need to nurture the learning of students' heritage languages in schools (Bialystok \& Poarch, 2015).

Large-scale achievement studies examining the potential of multilingual learners with regard to the learning of English as a foreign language (EFL) support the assumption that immigrant students show a slight advantage concerning their English proficiency compared to that of their German-speaking peers. Results from a large-scale study in primary schools in Hamburg (KESS-Study) reports a language learning advantage for immigrant learners (May, 2006). Analysis of another German large-scale study focusing on the language proficiency of 9th graders (DESI-study) can arguably likewise show the positive effect of a multilingual background on foreign language achievement (Hesse, Göbel, \& Hartig, 2008). In the DESI-study, three different learner groups were compared: students speaking German as a first language, students speaking a language other than German as a first language, and students speaking both, German and another language concurrently as first language (multilinguals). Multilingual students, as well as students with a first language other than German, showed a slight but substantial advantage concerning their outcome in the English tests as compared to monolingual German students with comparable learning preconditions. In addition, classrooms composed with a higher amount of bilingual students showed positive effects on the language learning results of the entire class. The DESI results give evidence to the assumption that a multilingual learning environment is beneficial for the acquisition of English as a foreign language in terms of the individual student and of the entire class (Hesse, Göbel, \& Hartig, 2008).

The most prominent claim about language learning in a multilingual environment is the language transfer-hypothesis of Jim Cummins (2000) that suggests a positive impact of language competence in L1 to the language competence in L2. Actual empirical data from the DESI-study and from other large-scale studies confirm the relevance of this assumption (Edele \& Stanat, 2015; Hesse, Göbel, \& Hartig, 2008; Rauch, 2014). The language systems within the individual seem to be in continuous interaction; changes in one linguistic system might have an effect on other linguistic systems (Hufeisen \& Jessner, 2009). Language skills in reading, listening, writing and speaking, as well as the making of inferences (in the sense of productive conclusions) are transferred from one language to another, while inferences have the tendency to 
be more correct the more similar the languages of reference are (Cenoz \& Genese, 1998). However, a special bridging function for further language learning is assigned to the first acquired foreign language (Meißner \& Senger, 2001). The different language systems are in continuous adaptation and are becoming more interdependent (Hufeisen \& Marx, 2010).

Learners can make use of language competence in other languages than the language being learnt in order to solve the linguistic task. They can learn to build bridges between their available language competences or to develop contrasts between them (Hufeisen \& Marx, 2010; Meißner \& Morkötter, 2009). The systematic use of former languages is a metacognitive strategy for language learning and the knowledge about how to master the learning process has been proven to be relevant for the learning outcomes. Besides the knowledge, it is the actual use of strategies and their appropriateness to the learning task that are important for the learning outcome (Artelt \& Neuenhaus, 2010). The spontaneous use of transfer strategies is supposed to only happen among so-called "good language learners", whereas weaker learners need instruction to be trained to make use of linguistic transfer opportunities. Thus, students can improve their language abilities when possibilities for inferences, linguistic knowledge, and learning strategies are taught in a systematic way (Hufeisen, 2006).

Intercomprehensive strategies and reflection of languages play a special role in the learning process, thus prior linguistic knowledge can be used to decode unknown texts in a new language and hypotheses are made about the structure of the target language (Hufeisen \& Jessner, 2009). Therefore, the use of native languages and other language learning experiences in class can be a benefit for promoting language learning and a positive perspective on the existing multilingualism in class (Krumm, 2005). Several didactical concepts aim at raising the awareness of linguistic phenomena, like searching for familiar linguistic structures in new linguistic contexts, making use of language comparisons from the first and second languages and the target language. The recognition of comparable items on different linguistic levels, such as morphology, lexemes/vocabulary, pronunciation, syntax and language learning strategies are being instructed within the language learning class (f.e. Behr, 2007; Hufeisen \& Neuner, 2003; Klein \& Stegmann, 2000; Meißner, 2005).

Still, the so-called "monolingual habitus" of German schools (Gogolin, 2008, 2013) entails a systematic lack of social esteem for multilingual students. It denotes an unexpressed habitual presupposition of homogeneity of students' linguistic and cultural experiences, while presupposing the normality of a monolingual socialization in the majority language. This immanent attitude is reflected in different educational structures and processes. For example, the monolingual attitude is reflected, in a lack of rewards (e.g. grades) for linguistic competencies in any other language different from the majority language and a few specific foreign languages that are also taught in school (in Germany, those languages are predominantly English, French, and Spanish). Furthermore, a monolingual attitude is represented in 
teaching materials, teachers' questions, hints and scaffolds, which are constructed according to the majority language and culture and, thus, consequently form an obstacle for students socialized in a different language in terms of comprehending the content of the lesson (Gogolin \& Kroon, 2000). A „pedagogy of plurality“ as e.g. developed by Prengel (2006), on the other hand, centers on an intersubjective recognition between individuals who are different but equal, and avoids all forms of discrimination. With regard to multilingualism, it questions monolingual assumptions, addresses the needs of children with different linguistic socializations, and values and rewards all linguistic abilities not only those in the majority language. Strategies to promote language transfer in EFL teaching can be considered to be a possible contribution to achieving this objective.

There is still little empirical research on the effect of language transfer promoting instruction on language and intercultural learning (Göbel \& Schmelter, 2016). Empirical studies in this field are still rare, but international comparative studies show that language teachers give little attention to the linguistic preconditions of their students (De Angelis, 2011). Firstly, results on language learning indicate that the synergetic use of different language abilities in the sense of a systematic comparison of linguistic repertoires seem to be most effective when learning German as a third language (Marx, 2005). Results on EFL-teachers' perspectives on language transfer promoting conceptions reveal that teachers agree about the relevance of language transfer promoting instruction but they report little use of this strategy in their teaching (Göbel, Vieluf, \& Hesse, 2010). Furthermore, results of the same study indicate that teachers' attitudes towards language transfer promoting teaching and their perception of the implementation of it into their teaching is positively correlated with the overall English competence of the students in class (Göbel et al., 2010; Göbel \& Vieluf, 2014).

The following contribution seeks to further analyze language transfer promoting instruction in the context of English as a foreign language instruction in $9^{\text {th }}$ grade secondary classes in Germany. By using questionnaires, tests, and video-data, we want to know which learning processes language transfer promoting instruction mediates and how teachers encourage interlanguage reflection in ESL-teaching.

\section{Research questions}

Via reanalyzing data gathered within the DESI study (Deutsch-Englisch-Schülerleistungen International / Assessment of Student Achievement in German and English as a Foreign Language; DESI Konsortium, 2008), the following study aims to examine whether teachers' self- reported practice concerning language transfer promoting teaching have an influence on learners' achievement levels in the EFL subdomains of reading comprehension and text reconstruction, and furthermore how teachers apply language transfer concepts in their EFL-classes. We will look at the following aspects: 
1. Is the self-reported practice of teachers concerning language transfer promotion linked to achievement gains in EFL listening comprehension and text reconstruction?

2. How do teachers with a high self-reported practice concerning language transfer promoting teaching actually implement language transfer in their teaching in class?

\section{Design and results of the studies}

The following paper is divided into two sub-studies: The first sub-study uses a quantitative approach and relates teachers' self-reported use of language transfer promotion to classroom and learning outcomes (Study I). The second sub-study is a qualitative study of selected videos of EFL-classes (Study II). Both analyses are based on data gathered within the context of the DESI-study. The DESI-study assessed at the beginning (T1) and end (T2) of the school year 2003/2004 German and EFL competencies as well as information on educational input and processes that are general characteristics of 9th grade students in Germany. In the course of the DESI-study a video-study on $104 \mathrm{EFL}$-classrooms was realized (DESI-Konsortium, 2008). Study I uses quantitative data from the DESI-study on language achievement and language instruction in order to reveal the relevance of language transfer promoting instruction on achievement in a longitudinal data set, while study II presents a video analysis from a selection of videos in order to describe the implementation of language transfer promoting teaching.

\subsection{Study I: The link between language transfer promoting teaching and student achievement in English as a foreign language}

\subsubsection{Research aim of Study I}

Study I aimed to examine whether or not teachers' self reports concerning language transfer promotion in EFL teaching are associated with changes in students' listening comprehension and text reconstruction in the course of grade 9 .

\subsubsection{Method of Study I}

\section{Participants}

The sample drawn for the DESI-study was representative for the target population of

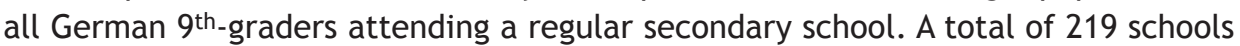
and two classes within each school were sampled randomly. Participation in the study was compulsory for all students in these classes. Sampling weights were constructed to account for unequal probability of selection and all statistics reported in this article were computed based on these weights. Data from 9,502 students attending $381 \mathrm{EFL}$ classes was used for study I. The average age of these students 
was 15 years at the beginning of Grade 9 , with $53 \%$ girls and $47 \%$ boys. $83 \%$ of the students reported they had learned German as their first language, $11 \%$ had learned another language than German, and 6\% had learned German and another language as their first languages.

\section{Measures}

The variables used for study I were based on student achievement tests as well as student and teacher questionnaires. Descriptions for all study variables are presented in the Appendix.

\section{Achievement data}

EFL achievement was assessed at the beginning (T1) and the end (T2) of school year $2003 / 2004$ by a test covering the content prescribed in the German federal states' curricula for grade 9 . For the following analysis, data from two-point measurement of listening comprehension and text-reconstruction tests are integrated. The tests had been developed by collaborating experts of applied linguistics, educational testing, and school education (Beck \& Klieme, 2007; DESI-Konsortium, 2008). The longitudinal scaling of the test was developed based on a multidimensional Rasch model (e.g., Briggs \& Wilson, 2003), where each time point was represented as one dimension. In our analyses, we used plausible values obtained from this model. The reliability estimated from independent plausible value draws (EAP/PV reliability; e.g., OECD, 2009) was 0.70 for both occasions of measurement.

\section{Language transfer promotion}

A four-item scale based on teachers' self-reports assessed language transfer promotion in EFL classes. Teachers were asked about their use of foreign languages other than English as well as their use of the native languages of the students in their classrooms during EFL instruction. Responses included: "I use the different languages available to the students by referring to their native languages or other foreign languages, for instance, by drawing comparisons during my lessons"; "I relate to the students' native languages and other foreign language competences during my lessons by including their lexicon"; and "I relate to the students' language competences regarding their native language and other foreign languages by relating to pragmatics". Another question concerned teachers' attitudes towards language transfer. A common response to this topic was: "I believe that it is generally helpful to refer to students' native languages and foreign languages during language lessons". For each item, a 4-point Likert response scale was used (where $1=$ fully agree to $4=$ I do not agree at all). Items were re-coded so that a high score represents a highly perceived frequency or significance of language transfer promotion in German language and EFL classes and a low score represents a low perceived freuquency or significance. The internal consistency (Cronbach's alpha) was $\alpha=0.88$ and confirmatory factor analysis supported a good model fit for the scale (CFI $=0.96$, RMSEA $=0.04$ and SRMR $=0.04$ ). 


\section{Control variables}

Four student variables were included as control variables. Students' basic cognitive abilities were assessed by the Figure Analogies subscale of the German version of the Cognitive Ability Test (Thorndike \& Hagen, 1993), which is highly related to aspects of general intelligence and represents a parsimonious measure of basic cognitive abilities. Students' sex was assessed in the tracking form and was available for all students in the study. Socioeconomic status (SES) of students' families was measured by the International Socio-Economic Index of Occupational Status (ISEI; Ganzeboom, de Graaf, Treiman, \& de Leeuw, 1992). Parents' occupation was assessed in the parent questionnaire. ISCO codes (ILO, 1990) were assigned to the responses, which were then mapped according to the ISEI. The highest ISEI of both parents (HISEI) was included as an indicator of student SES. Finally, students were asked which language they had learned first in their families (mother tongue) to assess their first language. Drawing on research on multilingualism, three language groups were distinguished: (a) the group of monolingual German speakers; (b) the group of multilingual learners (in terms of early simultaneous multilingualism; these learners have acquired an additional language to German as their first language); and (c) the group of learners whose first language is not German (Hesse, Göbel \& Hartig, 2008).

The following control variables at the classroom-level were included: First, a dummy variable indicating whether the school offers bilingual instruction and, second, the school type ${ }^{1}$. Four school types were distinguished: Realschule, the intermediate level school type; Hauptschule, schools offering the least academically demanding track; and Gesamtschule, the comprehensive school that offers different tracks. These were included as dummy variables with Gymnasium, the most academically demanding school type, as the reference category.

\section{Multilevel latent change modeling}

We applied multilevel modeling (e.g., Hox, 2010; Raudenbush \& Bryk, 2002) because we were interested in the effects of teacher's language transfer promotion, a variable measured at the class level, on student learning in the subjects of German and EFL, which were measured at the student level. Achievement in these subjects was assessed at two time points. We applied models for latent change at the classroom level to predict the learning gains in these two subjects, (Steyer, Partchev, \& Shanahan, 2000). In these models, each measurement is represented by a latent variable and an additional latent variable is specified to express the relationships between these variables in terms of initial status and change. This implies that the achievement at $\mathrm{t} 2 \mathrm{~T} 2 \mathrm{Y}[\mathrm{T} 2]$ is specified as an additive function of the achievement at

1 The German school system separates students early into different tracks (in most of the German federal states after $4^{\text {th }}$ grade). "Gymnasium" is the academic track, leading to the degree necessary for university entrance. "Realschule" is the intermediate level school type. "Hauptschule" offers the least academically demanding track, also referred to as the vocational track. Finally, the "Gesamtschule" is a comprehensive school type that combines all three tracks. These tracks differ not only in their achievement composition, but also in curricula and pedagogical traditions. 
$110 \mathrm{t} 1 \mathrm{Y}[\mathrm{T} 1]$ and the latent change $\mathrm{Y}(\mathrm{Y}[\mathrm{T} 2]=\mathrm{Y}[\mathrm{T} 1]+\mathrm{Y})$. The residual variance of $\mathrm{Y}[\mathrm{T} 2]$ was restricted to zero for identification purposes. At both levels, the relationships between all predictor variables and the relationships between the residuals of all dependent variables were estimated freely. Thereby, the initial status factor captures differences between classrooms at time point 1 and the change factor captures differences between classrooms in change between time points 1 and 2 regarding the language achievement level.

In the next step, we predicted both initial status and change with the teacher's language transfer promotion. Additionally, we included several control variables in the model. At the student level, we measured the effects of the student's basic cognitive abilities, sex, SES and language used at home at T1 and T2. At the class level we controlled for the effects of the track and of bilingual instruction offered in the school on initial status and change in the class-average achievement in EFL. The resulting model is shown in figure 1 .

Student Level

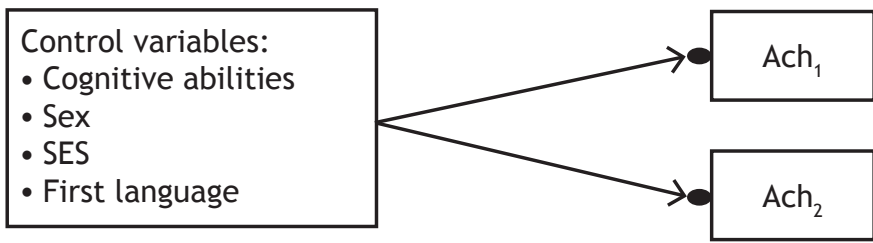

Class Level

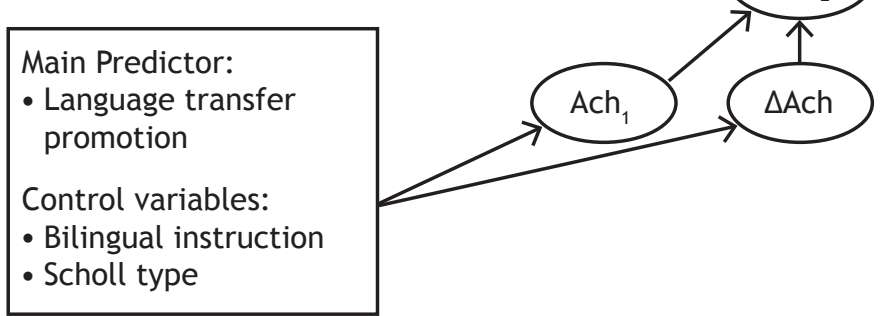

Figure 1 Illustration of the model for predicting the initial status and change in EFL achievement with language transfer promotion $\left(\mathrm{Ach}_{1}, \mathrm{Ach}_{2}\right.$ : achievement at $\mathrm{T} 1$ and $\mathrm{T} 2$ )

\section{Standardization and centering}

To facilitate the interpretation of results, all student-level predictors and outcomes are standardized using their overall mean and variance across students. Continuous class-level predictors (language transfer promotion) were also standardized by using their overall mean and variance across classes. Categorical predictors (bilingual instruction and scholl types) were effect coded. All student-level control variables were further centred on their grand mean as suggested by Lüdtke, Robitzsch, Trautwein and Kunter (2009). 


\section{Missing data}

The DESI-study applied a multi-matrix booklet design for the achievement tests, resulting in missing values by design, which was addressed by means of multiple imputation (Ml; Schafer \& Graham, 2002). Multiple imputations were also used to impute missing values for reports on families' socio-economic status. Missing data in the other predictors was addressed by applying the full information maximum likelihood algorithm (FIML; Arbuckle, 1996) in Mplus. A relatively high percentage of missing data was observed for the language transfer promotion variables (22-30\%) while the percentage or missing data observed for students' first language was smaller (7\%), and no missing data was observed for students' sex, bilingual instruction offered in school or school type (see also Appendix).

\section{Estimation and testing}

All models were estimated using robust maximum likelihood estimation (MLR) with the programme Mplus version 7.11 (Muthén \& Muthén, 1998-2012).

\subsubsection{Results of Study I}

Table 1 presents the results from multilevel latent-change models examining associations of language transfer promotion in EFL lessons with the classroom average achievement at the beginning of 9th grade and its change in the course of grade 9 .

The results show a positive link of language transfer promotion with EFL-listening comprehension at the beginning of grade 9. However, no association with changes during the course of grade 9 could be noted. In other words, classes in which teachers reported to support language transfer did not advance faster with regard to listening comprehension during the course of grade 9 than other classes. For text reconstruction, neither the initial status nor the change during grade 9 was associated with language transfer promotion. Hence, classes with a higher average achievement in the sub-domain of listening comprehension were more likely to be taught by teachers who reported more promotion of language transfer in EFL, but language transfer promotion was not a precursor to learning gains in the subdomains examined.

Effects of student control-variables also suggested that students with higher basic cognitive abilities and a higher SES, as well as students having German and another language as first languages, showed higher EFL achievement in both sub-domains at the beginning and at the end of grade 9. Effects of students' gender were more ambiguous: Girls appeared to be better at text reconstruction at both points in time, but had slightly lower than average values in listening comprehension at the beginning of grade 9. At class level, we observed effects of the school type and bilingual instruction offered in the school: achievement in EFL at the beginning of grade 9 was higher than average in classrooms of schools offering bilingual instruction as well as in the intermediate school type and lower in the lower school type as well as in comprehensive schools. Changes in EFL achievement were only predicted by school type. 
112 Table 1 Predicting Change in EFL competencies with language transfer promoting instruction

\begin{tabular}{|c|c|c|c|c|}
\hline \multirow[t]{2}{*}{ Variables } & \multicolumn{2}{|c|}{ text reconstruction $(B)$} & \multicolumn{2}{|c|}{ listening comprehension (B) } \\
\hline & T1 & $\begin{array}{c}\mathrm{T} 2 / \\
\mathrm{T} 2-\mathrm{T} 1 \mathrm{a}\end{array}$ & $\mathrm{T} 1$ & $\begin{array}{c}\mathrm{T} 2 / \\
\mathrm{T} 2-\mathrm{T} 1 \mathrm{a}\end{array}$ \\
\hline \multicolumn{5}{|l|}{ Level 1: Students } \\
\hline Basic cognitive abilites & $.16^{* *}$ & $.18^{* *}$ & $.10^{* *}$ & $.15^{* *}$ \\
\hline Sex: female & $.07^{* *}$ & $.09^{* *}$ & $-.03^{* *}$ & -.01 \\
\hline Socio-economic status & $.03^{* *}$ & .01 & $.03^{* *}$ & $.04^{* *}$ \\
\hline FL: other than German & $-.05^{*}$ & $-.04^{*}$ & $-.04^{*}$ & -.02 \\
\hline FL: German and another & $.07^{* *}$ & .04 & $.08^{* *}$ & $.04^{*}$ \\
\hline$R^{2}$ & .05 & .08 & .05 & .08 \\
\hline \multicolumn{5}{|l|}{ Level 2: Classes } \\
\hline Intercept & $-.28^{* *}$ & $.27^{* *}$ & $-.23^{* *}$ & $.37^{* *}$ \\
\hline Bilingual instruction & $.19^{* *}$ & .02 & $.24^{* *}$ & .05 \\
\hline Lower school type & $-.50^{* *}$ & $-.10^{* *}$ & $-.60^{* *}$ & $-.09^{*}$ \\
\hline Intermediate school type & $.15^{* *}$ & .00 & $.28^{* *}$ & -.03 \\
\hline Comprehensive school & $-.60^{* *}$ & .08 & $-.51^{* *}$ & .09 \\
\hline Language transfer promotion & .03 & .02 & $.06^{*}$ & -.01 \\
\hline$R^{2}$ & .63 & .03 & .64 & .03 \\
\hline
\end{tabular}

a At Level 1, the coefficients refer to students' individual achievement at T2; at Level 2, the coefficients refer to the classes' change in achievement between T1 and T2.

" $p<.05,{ }^{* *} p<.01,{ }^{* * *} p<.001$ (two-tailed).

\subsection{Study II: Exploratory qualitative video analysis of language transfer promoting teaching of selected teachers}

\subsubsection{Research aim of Study II}

With regard to the finding that language transfer promoting perspectives of teachers are correlated with EFL achievement (see Study I), Study II aims at exploring and illustrating language transfer promoting sequences of teaching. The analysis was applied to videographed EFL-lessons in $9^{\text {th }}$ grade classes, which had been taken from the DESI-Video study (Helmke et al., 2008). The leading question is: how do teachers with a high score of self-reported language transfer promoting teaching implement language transfer promotion into their classroom discourse?

\subsubsection{Method of Study II}

\section{Participants}

The following analysis focuses on a selection of EFL-videos, which were recorded in course of the DESI-study. The DESI-video sample consists of a total of 104 videos of EFL-instruction. The videos document 90 minutes of EFL-teaching. Teachers and students who participated in the video study were part of the DESI-sample as 
described in chapter 3.1.2 (see Helmke et al., 2008). In order to find out about actual language transfer promoting teaching practice in the EFL-lessons, we selected teachers with a high language transfer promotion score (extreme group selection). The selection presented is a sample of three classes where teachers had a language transfer promotion score that was higher than $85 \%$ of the teachers in the complete DESI-sample. For each teacher, video recordings and transcriptions were available for their 90 minutes of EFL-teaching with their $9^{\text {th }}$ grade students. These teachers were instructed to spend 45 minutes of the videographed lesson on a language-oriented topic and 45 minutes on an intercultural topic.

\section{Qualitative analysis of videotaped lessons}

The selected videographed classes were analysed by applying interaction analysis according to Krummheuer and Naujok (1999). In their analytical concept, Krummheuer and Naujok (1999) define teaching as a complex progression of actions by different persons - mainly teacher and students. In order to identify language transfer promoting teaching in this interaction, two independent and trained raters (teacher students from the University of Wuppertal; one male, one female) scanned the 3 videos aiming to discover sequences within the videos in which language transfer promoting teaching took place. The selection of sequences was synchronized by communicative validation of the raters. The interaction analysis of the selected sequences was realized independently for each sequence by each rater, according to the systematic of interaction analysis (Krummheuer, 2010): 1. Structuring of the sequence, 2. General description of the sequence, 3. Turn by turn interpretation of the sequence, where every turn is interpreted in at least two ways, 4. Concluding interpretation of the sequence. After the process of analysis, the raters came together for a structured communicative validation phase, in which they compared their interpretations and aggregated their analysis into a common analysis for each selected sequence according to the system of interaction analysis.

\subsubsection{Results of Study II}

\section{Results of sequence selection}

A total of 10 sequences with a potential for language transfer promotion could be selected from the 3 videos. The sequences can be divided into those which actually realized language transfer promotion $(n=3)$ and those which represented only opportunities for language transfer promotion $(n=7)$. The language transfer promoting initiatives were brought about by teachers or by students. The following table (Table 2) shows the distribution of the selected sequences within the selected lessons. Sequences were as long as 5-11 turns each. In 3 of the sequences, the teachers took the chance to promote language transfer, whereas in the remaining 7 sequences the teachers did not take advantage of the opportunity to direct the classroom talk to language transfer promotion (see Table 2). The results of further turn-by-turn analysis (common description and concluding interpretation) are presented for the 3 sequences where language transfer promotion was actually put into effect. 
114 Table 2 Overview of sequences with language transfer promotion and opportunities for language transfer promotion in the analysed videos

\begin{tabular}{|c|c|c|c|c|}
\hline & & & $\begin{array}{l}\text { Initiation } \\
\text { by student }\end{array}$ & $\begin{array}{l}\text { Initiation } \\
\text { by teacher }\end{array}$ \\
\hline \multirow{6}{*}{$\begin{array}{l}\text { Lesson with } \\
\text { language } \\
\text { learning focus }\end{array}$} & \multirow{2}{*}{$\begin{array}{l}\text { Class } 1 \\
\text { Topic: British } \\
\text { School System }\end{array}$} & $\begin{array}{l}\text { Language transfer } \\
\text { promotion }\end{array}$ & & $11: 40$ \\
\hline & & $\begin{array}{l}\text { Opportunity for language } \\
\text { transfer promotion }\end{array}$ & & $23: 14,35: 27$ \\
\hline & \multirow{2}{*}{$\begin{array}{l}\text { Class } 2 \\
\text { Topic: Wedding }\end{array}$} & $\begin{array}{l}\text { Language transfer } \\
\text { promotion }\end{array}$ & $33: 40$ & \\
\hline & & $\begin{array}{l}\text { Opportunity for language } \\
\text { transfer promotion }\end{array}$ & $29: 13$ & \\
\hline & \multirow{2}{*}{$\begin{array}{l}\text { Class } 3 \\
\text { Topic: Jobs }\end{array}$} & $\begin{array}{l}\text { Language transfer } \\
\text { promotion }\end{array}$ & & \\
\hline & & $\begin{array}{l}\text { Opportunity for language } \\
\text { transfer promotion }\end{array}$ & $17: 39$ & $05: 33$ \\
\hline \multirow{6}{*}{$\begin{array}{l}\text { Lesson with } \\
\text { intercultural } \\
\text { focus }\end{array}$} & \multirow{2}{*}{$\begin{array}{l}\text { Class } 1 \\
\text { Topic: British } \\
\text { School System }\end{array}$} & $\begin{array}{l}\text { Language transfer } \\
\text { promotion }\end{array}$ & & $13: 34$ \\
\hline & & $\begin{array}{l}\text { Opportunity for language } \\
\text { transfer promotion }\end{array}$ & & \\
\hline & \multirow{2}{*}{$\begin{array}{l}\text { Class } 2 \\
\text { Topic: Virtual } \\
\text { Wedding }\end{array}$} & $\begin{array}{l}\text { Language transfer } \\
\text { promotion }\end{array}$ & & \\
\hline & & $\begin{array}{l}\text { Opportunity for language } \\
\text { transfer promotion }\end{array}$ & $11: 40$ & \\
\hline & \multirow{2}{*}{$\begin{array}{l}\text { Class } 3 \\
\text { Topic: Job } \\
\text { Interview }\end{array}$} & $\begin{array}{l}\text { Language transfer } \\
\text { promotion }\end{array}$ & & \\
\hline & & $\begin{array}{l}\text { Opportunity for language } \\
\text { transfer promotion }\end{array}$ & $08: 33$ & \\
\hline
\end{tabular}

Note: Numbers indicate the starting point of time within the video.

\section{Turn-by-turn analysis of language transfer promoting sequences}

The sequences identified as actually showing language transfer promotion comprise two teacher-initiated cases and one case in which a student initiated it.

The first sequence was detected in an EFL-lesson that dealt with the British school system while having a language learning focus.

Class 1: Transcript of the video sequence, first lesson, language-learning topic (time: 11.40-13.33 min.)

.....

T More formal. What means more formal? Something is more formal. Clothes (!) are formal or informal. If you go to a wedding, for example, your wear a suit, and this is formal... clothing, right? So what is formal? It is the ... same word in German. Absolutely the same. We only spell it different or we read it different. What is... Read it German this wort (!), eh, word formal."

S Formal 
T Aha, there you are. Formal and formal. Now, an attitude means how you behave. Dominik, so what do you think it means? How you behave?

$S(?)$

T Bitte?

$\mathrm{S}$ The behavior is better

$\mathrm{T}$ The behavior in these schools is more formal, that means, you say better. So what do you think is a, eh, formal behavior? When you meet somebody for example? What is formal, Amagan?

S I don't know.

$\mathrm{T}$ What is formal? When you meet me at school. Do you meet me formal or are you just saying Hello? Hi Miss Hain?

S I meet you formal.

T Do you? No, you never did (laughing). What would be formal? Good morning Mrs. Haimann, how are you? Have you had a nice evening? Right?! So this is formal (laughing)...

The teacher explained the word "formal" by referring to two different examples. First, she described the word in the context of clothing, telling the students that wearing a suit at a wedding is formal and that other clothes, in contrast to that, could be regarded as informal. Additionally, she referred to the German word "formal" by asking a student to read out the English word using German pronunciation. By pointing the students to the phonological differences of the word while telling them that it has the same meaning in both languages, she embedded active language transfer promotion. After that, she continued by reading out the word "formal" in both languages again and, apparently assuming that the meaning of the word became clear, asking a student to associate its meaning with the word "attitudes". However, the student had difficulties with this task. The reason for the problems may, on the one hand, have been due to the way the teacher phrased the question and, on the other, to the students' lack of knowledge regarding the meaning of the German word "formal". Finally, the teacher described "formal behavior" by providing another example referring to formal greetings in the school context. The examples given by the teacher and the comparison of the English and German word were useful, however, the turn-by-turn analysis of this sequence shows that the examples provided did not seem to help the students in understanding the word as they seem to lack previous knowledge regarding the meaning of the German word "formal" and, therefore, were not able to transfer its meaning to the English equivalent.

The second sequence showing language transfer promotion was detected in the same class, dealing with the British school system, but this time in a lesson having an intercultural focus.

Class 1: Transcript of the video sequence, second lesson - intercultural topic (time: 13.40-14.06 min.)

S And sometimes the parents look for a place in these Independent Schools before their childrens are born

T Children 
S Children are born, and then, eh, they go ... sometimes go to school when they are only 3 years old

$\mathrm{T} \quad$ Alright. So earlier than that (points to the slide). What do we call that age with 3 when chil..children go to school? So, we don't have it here

Class (silence)

T You know kindergarden? Ne. This is already the the age...........

Students and teacher were discussing the age at which children start going to school in Great Britain and compared it to its equivalent in Germany. During the discussion, one of the students explained that children in Great Britain started going to school at the age of 3 . In response to that, the teacher asked the students what the German institution for children at that age was called, probably hoping for them to say "kindergarten age". As the students did not respond to that question, the teacher introduced the word "kindergarten" without explicitly explaining it, so that the language transfer given in that sequence has to be regarded as implicit. The teacher probably assumed that the students would understand the new word due to its similarity to the German expression. However, an explicit language transfer promotion would also have been possible in this situation and could have been realized by explaining the derivation of the English "kindergarten".

The third sequence provides an example of language transfer promotion initiated by a student in a lesson with a language learning focus dealing with the topic "wedding".

Class 2: Transcript of the video sequence, lesson with language learning focus (time: min. 33.40-34.05 min.)

$S$ What's "Affaire" in English?

T Affäre is affair, just eh leave out the e at the end, yeah, affair, to have a, to have, have an affair

S Mit "f"?

T Eh, double f, yeah, a double f. To have an affair.

While students were working on a task, one of them asked the teacher for the English equivalent of the German word "Affäre". The teacher responded by translating the word into English and pointing out the orthographic differences in comparison to the German word. She also provided possible contexts, in which the word could appear (e.g., having an affair). By translating the word herself, the teacher performed the language transfer, but did not really explain it. In order to help and support the student in finding the right word for herself, the teacher could have referred to the students' previous knowledge of other languages (e.g., French). The teacher's explanation of the word was followed by a further question from the student. She wanted to know whether "affair" was written with one or two " $f$ ". The teacher answered, once again providing a context in which the word could appear. The fact that the student had to ask this second question indicates that she did not know the spelling of the word "Affäre" in German. The sequence reveals that language transfer promotion needs proficiency of students in the referred language. If there is a lack of linguistic proficiency, like here in orthography, 
then explicit language transfer promotion needs scaffolding in order to be effective in the given situation.

The results of interaction analysis show that language transfer promoting sequences did occur in the videographed teaching of teachers with a high score of language transfer promoting teaching. Two of the three teachers displayed active language transfer promotion in their teaching, realizing short sequences within their lessons, where language transfer to German language took place. However, the seizing of language transfer has been integrated in a rather implicit way, and referring to the German language only. Several opportunities for language transfer within the videos were detected by the raters, which had not been embraced by the teachers.

\section{Discussion}

Concerning sub domains of student achievement in EFL, regression analyses revealed a positive correlation of language transfer promoting teaching with EFL listening comprehension at the beginning of grade 9. Classes with a higher average achievement in the sub-domain of listening comprehension were more likely to be taught by teachers who reported more promotion of language transfer in EFL. Still, a correlation of language transfer promoting practices with the rise of competences in EFL could not be revealed. Interestingly, the correlation between language transfer promoting teaching did not show up with text reconstruction, but receptive language competence only. This seems to confirm the discussion on language transfer promoting teaching strategies that assumed that they are helpful above all to enhance receptive linguistic competence (e.g. Behr, 2007; Hufeisen \& Neuner, 2003; Klein \& Stegmann, 2000; Meißner, 2005). The positive correlation could be interpreted as teachers wanting to promote linguistic transfer in those classes where listening comprehension is higher. It could also possibly be the result of more long-term effects of language transfer promotion on student learning - if the same teachers had been teaching English in the same class for a longer period of time, which we don't know. Further research could test longitudinal effects of language transfer over a longer period of time.

The analysis of selected videos revealed that sequences that hint at an attempt to promoting language transfer actually take place in classes of teachers reporting high importance for language transfer promoting teaching. However, these sequences do not display an elaborated language transfer promoting teaching. Language transfer promotion is implemented in a rather implicit way, while referring to German language only. Furthermore, we could observe more opportunities for language transfer promotion, but teachers did not embrace them. Although language teaching is supposed to address multilingualism (Hufeisen, 2006; Krumm, 2005), teachers often do not correspond to this goal (de Angelis, 2011). In addition, it appears that teaching material is not as well prepared for multilingual issues 
118 for how teachers might need it (Marx, 2014). Our results somewhat confirm these findings by showing that language transfer promotion is seldom applied in teaching, and if ever, is not made explicit and not very elaborated - even among teachers who strongly support language transfer promotion in ESL teaching. Teachers do not seem to have a systematic didactical approach to implement it. This might also explain why we did not observe associations of language transfer support with student achievement gains in ESL - even in classrooms of language transfer supporters such strategies might be implemented too seldom and not in skilled enough manner to have a noticeable effect on language learning. In order to help students to understand language-transferring strategies, an explication of the transfer strategy would be useful. Furthermore, the analyzed videos show transfer perspectives to German language only, but as today's classrooms have students with differing linguistic backgrounds, teachers could make use of this resource and address transfer perspectives towards students' L1. Still, it is unknown to what extent the concept of language transfer promoting teaching, as developed in the context of multilingualism theory and didactics, can be adopted to the language teaching of learners with another first language than the lingua franca in school. This perspective should be considered in future research.

To conclude, teachers should be supported to more actively and explicitly incorporate language transfer promotion into their teaching. Therefore, further research on the impact of language transfer promoting instruction is needed as well as research on the systematic training and development of teaching material for an explicit implementation of linguistic transfer perspectives into daily language teaching (Göbel \& Vieluf, 2014; Göbel \& Schmelter, 2016). An important basis for the construction of trainings and didactical materials would be a qualitative research focus on the processes underlying classroom discourse, like in terms of the way students from different linguistic background respond to language transfer promoting instruction, and on teachers' subjective theories about multilingualism and the implementation of language transfer promoting teaching.

\section{References}

Arbuckle, J. L. (1996). Full information estimation in the presence of incomplete data. In G. A. Marcoulides \& R. E. Schumacker (Eds.), Advanced structural equation modeling (pp. 243-277). Mahwah, NJ: Lawrence Erlbaum Associates, Inc.

Artelt, C., \& Neuenhaus, N. (2010). Metakognition und Leistung. In W. Bos, O. Köller \& E. Klieme (Eds.), Schulische Lerngelegenheiten und Kompetenzentwicklung (pp. 127-146). Münster: Waxmann.

Beck, B., \& Klieme, E. (Eds.) (2007). Sprachliche Kompetenzen. Konzepte und Messung. DESI-Studie. Weinheim: Beltz.

Behr, U. (2007). Sprachübergreifendes Lernen und Lehren in der Sekundarstufe, I: Ergebnisse eines Kooperationsprojekts der drei Phasen Lehrerbildung. Tübingen: Gunter Narr.

Bialystok, E. (2005). Consequences of bilingualism for cognitive development. In J. R. Kroll \& A. de Groot (Eds.), Handbook of Bilingualism. Psycholinguistic Approaches (pp. 417-432). Oxford: Oxford University Press. 
Bialystok, E., \& Poarch, G. (2015). Bilingualism as a model for multitasking. Developmental Review, 35, 113-124.

Briggs, D. C., \& Wilson, M. (2003). An introduction to multidimensional measurement using Rasch Models. Journal of Applied Measurement, 4(1), 87-100.

Cenoz, J. (2003). The additive effect to bilingualism on third language acquisition: A review. The International Journal of Bilingualism, 7(1), 71-88.

Cenoz, J., \& Genese, F. (1998). Psycholinguistic perspectives on multilingualism and multilingual education. In J. Cenoz \& F. Genese (Eds.), Beyond Bilingualism. Multilingualism and Multilingual Education (pp. 16-34). Clevedon: Multilingual Matters.

Cummins, J. (2000). Language, power and pedagogy: Bilingual children in the crossfire. Clevedon, UK: Multilingual Matters Ltd.

De Angelis, J. (2011). Teachers' beliefs about the role of prior language knowledge in learning and how these influence teaching practices. International Journal of Multilingualism, 8(3), 216-134.

DESI-Konsortium (2008). Unterricht und Kompetenzerwerb in Deutsch und Englisch - Ergebnisse der DESI-Studie. Weihnheim: Beltz.

Edele, E., \& Stanat, P. (2015). The role of first language listening comprehension in second-language reading comprehension. Journal of Educational Psychology, 108(2), 163-180.

EU-Kommission (2005). Mitteilung der Kommission an das Europäische Parlament und den Rat: Europäischer Indikator für Sprachenkompetenz. Brüssel: Kommission der Europäischen Gemeinschaften.

Ganzeboom, H. B. G., de Graaf, P. M., Treiman, D. J., \& de Leeuw, J. (1992). A standard international socio-economic index of occupational status. Social Science Research, 21, 1-56.

Göbel, K., \& Schmelter, L. (2016). Mehr Sprachen - mehr Gerechtigkeit? In I. Dirim \& A. Wegner (Hrsg.), Mehrsprachigkeit und Bildungsgerechtigkeit (pp. 271-286). Opladen: Barbara Budrich Verlag.

Göbel, K., \& Vieluf, S. (2014). The effects of language transfer promoting instruction. In P. Grommes \& A. Hu (Eds.), Plurilingual Education: Policies - Practice - Language Development (pp. 183-197). Amsterdam: John Benjamins.

Göbel, K., Vieluf, S., \& Hesse, H. G. (2010). Die Sprachentransferunterstützung im Deutschund Englischunterricht bei Schülerinnen und Schülern unterschiedlicher Sprachlernerfahrung. Zeitschrift für Pädagogik, 55 (Beiheft), 101-122.

Gogolin, I. (2008). Der monolinguale Habitus der multilingualen Schule. Internationale Hochschulschriften (Vol. 101). Münster: Waxmann.

Gogolin, I. (2013). The "monolingual habitus" as the common feature in teaching in the language of the majority in different countries. Per Linguam, 13, 38-49.

Gogolin, I., \& Kroon, S. (2000). Einsprachige Schule, mehrsprachige Kinder: Erfahrungen aus einem international vergleichenden Projekt über Unterricht in der Sprache der Majorität. In I. Gogolin, \& S. Kroon (Eds.), 'Man schreibt wie man spricht': Ergebnisse einer international vergleichenden Fallstudie über Unterricht in vielsprachigen Klassen (pp. 1-25). Münster / New York: Waxmann Verlag.

Helmke, A., Helmke, T., Schrader, F. W., Wagner, W., Klieme, E., Nold, G., \& Schröder, K. (2008). Wirksamkeit des Englischunterrichts [Efficacy of EFL teaching]. In DESI-Konsortium (Ed.), Unterricht und Kompetenzerwerb in Deutsch und Englisch (pp. 382-397). Weinheim: Beltz.

Hesse, H. G., Göbel, K., \& Hartig, J. (2008). Sprachliche Kompetenzen von mehrsprachigen Jugendlichen und Jugendlichen nicht-deutscher Erstsprache. In DESI-Konsortium (Ed.), Unterricht und Kompetenzerwerb in Deutsch und Englisch. Ergebnisse der DESI-Studie (pp. 208-230). Weinheim: Beltz.

Hox, J. J. (2010). Multilevel Analysis. Techniques and Applications. New York: Routledge.

Hufeisen, B. (2006). Mehrsprachigkeitsdidaktik. In U. O. H. Jung (Ed.), Praktische Handreichung für Fremdsprachenlehrer (pp. 530-537). Frankfurt: Peter Lang.

Hufeisen, B., \& Jessner, U. (2009). Learning and teaching multiple languages. In K. Knapp \& B. Seidlhofer (Eds.), The Handbook of Applied Linguistics, Vol. 5: Foreign Language Learning and Communication (pp. 109-137). Berlin: Mouton de Gruyter. 
Hufeisen, B., \& Marx, N. (2006). Auf dem Weg von einer allgemeinen Mehrsprachigkeitsdidaktik zu einer spezifischen DaFnE-Didaktik. Fremdsprachen Lehren und Lernen (FLuL), 34, 146-155.

Hufeisen. B., \& Marx, N. (2010). Mehrprachigkeitskonzepte. In H. J. Krumm, C. Fandrych, B. Hufeisen, \& C. Riemer (Eds.), Handbuch Deutsch als Fremd- und Zweitsprache (pp. 826-832). Berlin, New York: Mouton de Gruyter.

Hufeisen, B., \& Neuner, G. (2003). Mehrsprachigkeitskonzept - Tertiärsprachen - Deutsch nach Englisch. Strasbourg: Council of Europe.

International Labour Office (1990). International Standard Classification of Occupations. ISCO - 88. Genf: ILO.

Jessner, U. (2008). Teaching third languages: Findings, trends and challenges. State-of-the-art article. Language Teaching, 41(1), 15-56.

Klein, H. G., \& Stegmann, T. D. (2000). EuroComRom - Die sieben Siebe. Romanische Sprachen sofort lesen können. Aachen: Editions EuroCom.

Krumm, H. J. (2005). Von der additiven zur curricularen Mehrsprachigkeit: Über die Notwendigkeit der Einbeziehung von Minderheiten-, Migranten- und Nachbarsprachen. In B. Hufeisen \& M. Lutjeharms (Eds.), Gesamtsprachencurriculum . Integrierte Sprachdidaktik - Common Curriculum (pp. 27-36). Tübingen: Günter Narr.

Krummheuer, G. (2010). Die Interaktionsanalyse. In F. Heinzel (Ed.), Methoden der Kindheitsforschung. Weihnheim: Juventa.

Krummheuer, G., \& Naujok, N. (1999). Grundlagen und Beispiele Interpretativer Unterrichtsforschung. Opladen: Leske + Budrich.

Lüdtke, O., Robitzsch, A., Trautwein, U., \& Kunter, M. (2009). Assessing the impact of learning environments: How to use student ratings of classroom or school characteristics in multilevel modeling. Contemporary Educational Psychology, 34(1), 120-131.

Marx, N. (2005). Hörverstehensleistungen im Deutschen als Tertiärsprache. Baltmannsweiler: Schneider.

Marx, N. (2014). Häppchen oder Hauptgericht? Zeichen der Stagnation in der deutschen Mehrsprachigkeitsdidaktik [Starter or main course? Signs of stagnation in German multilingal didactics]. Zeitschrift für Interkulturellen Fremdsprachenunterricht (ZiF), 1, 8-24.

May, P. (2006). Englisch-Hörverstehen am Ende der Grundschulzeit. In W. Bos \& M. Pietsch (Eds.), KESS 4 - Kompetenzen und Einstellungen von Schülerinnen und Schülern am Ende der Jahrgangsstufe 4 in Hamburger Grundschulen (pp. 203-224). Münster: Waxmann.

Mägiste, E. (1984). Learning a third language. Journal of Multilingual and Multicultural Development, 5, 415-421.

Meißner, F. J. (2005). Vorläufige Erfahrungen mit autonomen Lernern qua Mehrsprachenunterricht [Preliminary experiences with autonomous learning in multilingual teaching]. In B. Hufeisen \& M. Lutjeharms (Eds.), Gesamtsprachencurriculum . Integrierte Sprachdidaktik - Common Curriculum (pp. 129-135). Tübingen: Günter Narr.

Meißner, F. J. \& Morkötter, S. (2009). Förderung von metasprachlicher und metakognitiver Kompetenz durch Interkomprehension [Promotion of metalinguistic and metacognitive skills via intercomprehensive learning strategies]. FLuL, 38, 51-69.

Meißner, F. J. \& Senger, U. (2001). Vom induktiven zum konstruktiven Lehr-Lernparadigma. Methodische Folgerungen aus der mehrsprachigkeitsdidaktischen Forschung. In F. J. Meissner \& M. Reinfried (Eds.), Lernzentrierung, Ganzheitlichkeit, Handlungsorientierung, Interkulturalität, Mehrsprachigkeitsdidaktik (pp. 21-50). Tübingen: Gunter Narr.

Muthén, L. K., \& Muthén, B. O. (1998-2012). Mplus-statistical analysis with latent variables. Los Angeles, CA: Muthén \& Muthén.

Naiman, N, Fröhlich, M. Stern, H., \& Todesco, A. (1996). The good language learner. Clevedon: Multilingual Matters.

Organisation for Economic Cooperation and Development (2009). PISA 2006 technical report. Paris, France: OECD.

Prengel, A. (2006). Pädagogik der Vielfalt. Verschiedenheit und Gleichberechtigung in interkultureller, feministischer und integrativer Pädagogik. Wiesbaden: VS Verlag. 
Rauch, D. (2014). Effects of biliteracy on third language reading proficiency, the example of Turkish-German bilinguals. In P. Grommes \& A. Hu (Eds.), Plurilingual Education: Policies Practice - Language Development (pp. 199-218). Amsterdam: John Benjamins.

Raudenbush, S. W., \& Bryk, A. S. (2002). Hierarchical linear models: Applications and data analysis methods. Newbury Park, CA: Sage.

Schafer, F. L., \& Graham, J. W. (2002). Missing data: Our view of the state of the art. Psychological Methods, 72(2), 147-177.

Steyer, R., Partchev, I., \& Shanahan, M. J. (2000). Modeling true intraindividual change in structural equation models: The case of poverty and children's psychosocial adjustment. In T. D. Little, K. U. Schnabel, \& J. Baumert (Eds.), Modeling Longitudinal and Multilevel Data (pp. 109-126). Mahwah, NJ: Lawrence Erlbaum Associates.

Stanat, P., Rauch, D., \& Segeritz, M. (2010). Schülerinnen und Schüler mit Migrationshintergrund [Students with immigrant background]. In E. Klieme, C. Artelt, J. Hartig, N. Jude, O. Köller, M. Prenzel, W. Schneider, \& P. Stanat (Eds.), PISA 2009. Bilanz nach einem Jahrzehnt (pp. 200-230). Münster: Waxmann.

Thorndike, R. L., \& Hagen, E. P. (1993). Form 5 Cog AT. Norms booklet. Chicago, IL: Riverside. Vertovec, S. (2007). Super-diversity and its implications. Ethnic and Racial Studies, 30(6), 1024-1054.

Prof. Dr. Kerstin Göbel

Faculty of Education University of Duisburg-Essen Universitätsstraße 2

45141 Essen, Germany kerstin.goebel@uni-due.de

Dr. Svenja Vieluf German Institute for International Educational Research (DIPF) Schloßstraße 29

D-60486 Frankfurt am Main, Germany vieluf@dipf.de

\section{Appendix}

Descriptive Statistics for Variables Used in Study I for the Analysis of EFL Achievement.

\begin{tabular}{llll}
\hline Variable & $M$ & SD & $\%$ Missing \\
\hline
\end{tabular}

Sample used for analysis of achievement in EFL

Student level $(n=9,502)$

1. text reconstruction $\mathrm{T} 1$

$\begin{array}{rrc}515.16 & 99.12 & 0 \\ 540.34 & 104.62 & 0 \\ 509.86 & 94.35 & 0 \\ 541.48 & 104.56 & 0 \\ 52.69 & 9.65 & 7.55 \\ 0.53 & 0.50 & 0 \\ 51.35 & 16.05 & 7.77\end{array}$

2. text reconstruction $\mathrm{T} 2$

3. listening comprehension T1

4. listening comprehension $\mathrm{T} 2$

5. Basic cognitive abilities (KFT)

6. Sex: female

7. Socio-economic status (HISEI PV) 
8. First language: Other than German

9. First language: German and another

Class level $(n=381)$

1. Bilingual instruction

2. Lower school type (Hauptschule)

3. Intermediate school type (Realschule)

4. Comprehensive school type (Gesamtschule)

5. Cognitive composition (mean KFT)

6. Gender composition (\% girls)

7. Social composition (mean HISEI)

8. Linguistic composition (\% FL: other than German)

9. Linguistic composition (\% FL: German and another)

10. Language transfer promoting teaching - single items:

I believe that it is generally helpful to refer to students' native languages and foreign languages during language lessons.

I use the different languages available to the students by referring to their native languages or other foreign languages, for instance by drawing comparisons during my lessons.

I relate to the students' native languages and other foreign language competences during my lessons, by including their lexicon.

I relate to the students' language competences regarding their native and other foreign languages durin my lessons, by relating to pragmatics.
0.11
0.32
7.31
0.06
0.24
7.31

0.21

0.41

0

0.20

0.40

0

0.34

0.47

0

0.04

0.21

51.82

7.17

0

0.52

0.17

0

50.57

8.11

0

0

$\begin{array}{lll}0.12 & 0.14 & 0\end{array}$

$\begin{array}{lll}0.06 & 0.06 & 0\end{array}$

$\begin{array}{lll}2.27 & 0.86 & 24.41\end{array}$

$\begin{array}{lll}2.97 & 0.94 & 26.25\end{array}$

$\begin{array}{lll}2.86 & 0.90 & 27.03\end{array}$

$\begin{array}{lll}3.05 & 0.84 & 29.66\end{array}$

Note: All statistics are based on the original variables before standardization and effect coding. 